\title{
PROPAGANDA Y FUENTES DE INFORMACIÓN EN LA PRENSA PERIÓDICA DE LA AMÉRICA HISPANA DURANTE LAS GUERRAS DEL SIGLO XVIII ${ }^{1}$
}

\author{
David GonzÁlez CRUZ \\ Universidad de Huelva
}

\begin{abstract}
Resumen. Este trabajo de investigación analiza la prensa periódica de la América Hispana del siglo XVIII como instrumento informativo y vehículo propagandístico durante los procesos bélicos. En primer lugar, con este objetivo se expone un panorama general de la distribución geográfica de estos medios de comunicación escritos y, con posterioridad, se entra de lleno en el estudio de las fuentes periodísticas utilizadas para la difusión de las noticias en tiempos de guerra; de este modo, se atiende a las informaciones proporcionadas por las gacetas europeas, la prensa oficial española, los navíos de avisos, las denominadas "papeletas", las cartas de autoridades políticas o de particulares, entre otras. Asimismo, se pone de manifiesto el empleo de los papeles periódicos americanos en las estrategias propagandísticas de la Monarquía Hispánica en los periodos de enfrentamientos armados; no en vano, contribuyeron a divulgar mensajes adaptados a la mentalidad hispana y elaborados por el poder político, al tiempo que fueron utilizados como recursos complementarios de la logística del Ejército en el reclutamiento de soldados, la recaudación de "donativos" destinados a las operaciones militares, la "guerra psicológica" y la implicación de la población civil en la defensa de los territorios de la Corona.
\end{abstract}

Palabras clave: Periodismo, información, propaganda, periódicos, gacetas, guerra, historia de la prensa, América Hispana, siglo XVIII.

Recibido: 1 septiembre 2010 Aceptado: 2 diciembre 2010

1 Esta publicación ha sido realizada en el marco de dos proyectos de investigación financiados por el Ministerio de Ciencia e Innovación del Gobierno de España con cofinanciación europea FEDER; en concreto, "La imagen de los extranjeros y enemigos durante los conflictos bélicos del siglo XVIII en España y América" (referencia: HUM2007-60178/HIST) y "Extranjeros y pueblos indígenas en la mentalidad hispana del siglo XVIII: estrategias represivas y procesos de integración en España y América" (referencia: HAR2010-15141). 
Abstract. This paper analyzes the periodic press of Hispanic America of the 18th century as informative instrument and propaganda vehicle during the warlike processes. With this aim an overview of the geographical distribution of these print media is exposed and, subsequently, the journalistic sources used for the diffusion of the news in wartime are studied: the European gazettes, the official Spanish press, the ships of notices, the so-called papeletas, the letters of political authorities or individuals, and others. Likewise, the employment of the American newspapers in the propaganda strategies of the Hispanic Monarchy in the periods of armed clashes is revealed; not uselessly, they helped to spread messages adapted to the Hispanic mentality and were elaborated by the political power, at the time that they were used as complementary resources of the logistics of the Army in the soldiers' recruitment, the collection of donativos for the military operations, the "psychological warfare" and the implication of the civil population in the defence of the territories of the Crown.

Keywords: Journalism, information, propaganda, newspapers, gazettes, war, history of the press, Hispanic America, 18th century.

\section{La geografía de la prensa hispanoamericana ${ }^{2}$}

La América Hispana, desde comienzos del siglo XVIII, se constituyó en un centro receptor de los papeles periódicos editados en España y en los estados europeos, si bien necesitó esperar a la década de los años veinte para conocer la primera experiencia de creación de un medio de comunicación escrito con una periodicidad fija; en concreto, se trató de la Gaceta de México y Noticias de la Nueva España fundada en 1722; con posterioridad, en las décadas siguientes, el panorama de la prensa -a impulsos del movimiento de la Ilustración y del apoyo de las autoridades políticasse incrementó sustancialmente a lo largo de la geografía americana, principalmente en la segunda mitad de la centuria, mediante nuevos proyectos editoriales puestos en funcionamiento en Lima, Guatemala, Santa Fe de Bogotá, La Habana, Quito y Buenos Aires. De este modo, la mayor concentración de nuevas iniciativas periodísticas se observa en los últimos cincuenta años del siglo XVIII, tanto en los territorios de la Península Ibérica como en los ultramarinos ${ }^{3}$.

2 La inclusión de la distribución geográfica de los papeles periódicos en este artículo solamente pretende contextualizar el tema central, ya que como se indica en el resumen reseñado anteriormente el objetivo que se persigue es exclusivamente su análisis como fuente informativa y vehículo de comunicación propagandística durante las coyunturas generadas por los procesos bélicos. En este sentido, resulta complejo reflejar todos los resultados de mis investigaciones sobre la prensa hispana en sus diversas vertientes en un texto de formato de artículo de esta extensión; por ello, se trata de un avance de los estudios realizados, que está previsto sea complementado con la redacción de un libro sobre el funcionamiento del periodismo americano a lo largo del siglo XVIII en el que se contemplarían las diferentes variables que pueden ser objeto de análisis, cuyo trabajo se encuentra en proceso de elaboración.

3 Así se aprecia también en los estudios relativos a la prensa periódica editada en la España del Setecientos; entre otros pueden mencionarse: GUINARD, Paul J.: La presse espagnole de 1737 a 1791. 
Por su parte, el proyecto pionero de la ciudad de México respondía a la existencia de un mayor nivel de desarrollo cultural desde los inicios del Setecientos y a índices de alfabetización más elevados que en el resto de los núcleos urbanos de Indias; precisamente, el potencial de lectores en México y en el entorno de su Virreinato originaba que las ediciones de obras impresas tuvieran tiradas de ejemplares de similar magnitud a las que se publicaban en la Península Ibérica ${ }^{4}$. Con todo, las sedes centrales de los virreinatos de Nueva España y de Perú fueron los focos intelectuales más activos de esta centuria de manera que se generaron, por esta razón, varias publicaciones periódicas en cada una de ellas 5 ; así, en la capital mexicana, junto a su primera gaceta, nacieron de la imprenta otros papeles periódicos como el Mercurio de México, Asuntos varios sobre Ciencias y Artes, Diario Literario, Mercurio Volante y Gaceta de Literatura de México. En lo que respecta a la capital peruana fueron surgiendo a lo largo del Setecientos otros significados exponentes de la prensa hispana como la $\mathrm{Ga}$ ceta de Lima, el Mercurio Peruano, el Diario de Lima, curioso, erudito, económico y comercial, y el Semanario Crítico ${ }^{6}$. Del impacto de estas publicaciones en la sociedad indiana es expresivo el dato de que el Mercurio Peruano era leído por la mitad de la población blanca de Lima7 ${ }^{7}$ Por su parte, algunas de las ciudades que actuaban como cabeza política de las capitanías generales y audiencias consiguieron editar, en líneas generales, un solo papel periódico; es el caso de la Gaceta de Guatemala en la Capitanía General de su mismo nombre y de las Primicias de la Cultura de Quito. Sin embargo, la Capitanía General de Chile, con un amplio territorio bajo su jurisdicción, no dispuso de un órgano de comunicación escrito de carácter periódico diferente a la prensa publicada en la sede del Virreinato peruano. Esta realidad contrastaba de forma excepcional con la proliferación de instrumentos periodísticos en la Capitanía General

Formation et signification d'un genre, Paris, Centre de Recherches Hispaniques, 1973. URZAINQUI, Inmaculada: "Un nuevo instrumento cultural: la prensa periódica", en ÁLVAREZ BARRIENTOS, Joaquín, LÓPEZ, François, y URZAINQUI, Inmaculada: La República de las Letras en la España del siglo XVIII, Madrid, CSIC, 1995, pp. 125-215. AGUILAR PIÑAL, Francisco: "La prensa española en el siglo XVIII. Diarios, revistas y pronósticos”, Cuadernos Bibliográficos, XXV, Madrid, CSIC, 1978. SÁNCHEZ HITA, Beatriz: "La prensa en Cádiz en el siglo XVIII", El Argonauta Español, núm. 4, 2007. http://argonauta. imageson.org/document91.html

4 GUERRA, François-Xavier: Modernidad e independencias. Ensayos sobre las revoluciones hispánicas, México, Fondo de Cultura Económica, 1993, p. 281.

5 GONZÁLEZ CRUZ, David: "El ejército y los militares ante el «periodismo ilustrado» de la América Hispana", en Milicia y sociedad ilustrada en España y América (1750-1800). Actas de las XI Jornadas Nacionales de Historia Militar, tomo II, Madrid, Editorial Deimos, 2003, pp. 11-30.

6 Respecto a la vinculación de este papel periódico con el Diario de Cádiz puede verse: SÁNCHEZ HITA, Beatriz: Juan Antonio Olavarrieta/José Joaquín de Clararrosa: periodista ilustrado. Aproximación biográfica y Estudio del Semanario Crítico de Lima (1791) y del Diario de Cádiz (1796), Cádiz, Fundación Municipal de Cultura, 2009.

7 GUERRA, François-Xavier, op. cit., p. 107. 
de Cuba, donde las iniciativas político-culturales de sus dirigentes y de los intelectuales residentes en esta isla caribeña posibilitaron la fundación de varios noticiarios en las últimas cuatro décadas del siglo XVIII; entre ellos, se encontraban la Gaceta de la Habana, el Papel Periódico de la Havana ${ }^{8}$, y El Pensador. Por último, en lo que se refiere a los nuevos virreinatos creados en el siglo XVIII, la ciudad de Santa Fé de Bogotá -capital del nuevo reino de Granada- contó con dos proyectos de prensa: por un lado, la Gaceta de Santa Fe de Bogotá, de duración muy efímera, pues solamente vieron la luz tres o cuatro ejemplares en 1785 y, por otro, el Papel Periódico de Santa Fe de Bogotá en la década de los noventa9. En cuanto al Virreinato de La Plata se tiene constancia de un ensayo fugaz en 1764 protagonizado por la Gaceta de Buenos Aires $^{10}$, aunque la consolidación del género periodístico no se materializó hasta los primeros años del siglo XIX con la creación del Telégrafo Mercantil, Rural, PolíticoEconómico e Historiógrafo del Río de la Plata (1801) y con la posterior publicación del Semanario de Agricultura, Industria y Comercio (1802).

Este conjunto de papeles periódicos editados en la América Hispana no lograron convertirse en los únicos instrumentos monopolizadores de la información y de la propaganda en estas tierras ultramarinas; no en vano, la documentación analizada demuestra que las gacetas europeas circularon de forma constante con el objetivo de que los lectores del Nuevo Mundo conocieran las noticias acontecidas en la metrópoli y en el viejo continente. En este sentido, en los períodos de conflictos bélicos, en los que la prensa oficial ocultaba hechos en mayor medida que en épocas de paz o expresaba la realidad parcialmente por razones estratégicas, se prodigó la distribución de la prensa clandestina entre la población alfabetizada y los ilustrados que precisaban contrastar lo reflejado en los medios de comunicación dependientes de la Monarquía

8 El número de lectores de la prensa cubana es significativo del grado de desarrollo que alcanzó a fines del siglo XVIII; en concreto, el Papel Periódico de la Havana tenía una distribución media de 557 ejemplares por número. A modo comparativo, la cifra máxima de suscriptores del Mercurio Peruano fue de 517 y se calcula que el Diario de Lima no superaba los 100 ejemplares en 1791; por otro lado, en Europa, el Journal de Trévoux solamente tenía 330 suscriptores y El Correo de Madrid entre 265 y 300 . Vid. SÁNCHEZ BAENA, Juan José y CHAÍN NAVARRO, Celia: "Prensa e Ilustración. La elites cubanas y el control de la información a finales del siglo XVIII", en ANDREO GARCÍA, Juan, PROVENCIO GARRIGOS, Lucia y SÁNCHEZ BAENA, Juan José (eds.): Familia, tradición y grupos sociales en América Latina, Murcia, Universidad de Murcia, 1994, p. 175. MENDOZA MICHILOT, María: Inicios del periodismo en el Perú. Relaciones y noticiarios, Lima, Universidad de Lima, 1997, p. 51.

9 Aguilera CAStillo, César: "El Papel Periódico de Santa Fe de Bogotá", Estudios de historia social, 52-53 (1990), pp. 17-22.

10 Este papel periódico, impulsado trece años antes de que Carlos III adoptara la decisión de crear el Virreinato de La Plata, no logró la permanencia necesaria en el tiempo para contribuir de manera significativa a la difusión de las ideas ilustradas. La investigación realizada nos ha permitido encontrar un ejemplar manuscrito en el Archivo Nacional de Argentina; no obstante, la corta vida de esta publicación no ha posibilitado hallar algunos ejemplares impresos que aportaran más datos sobre la labor cultural e informativa desarrollada por esta gaceta. 
TABLA 1. Papeles periódicos de la América

Hispana, fecha de fundación y lugares de edición (1722-1801)

\begin{tabular}{|l|c|c|}
\hline DENOMINACIÓN DEL PAPEL PERIÓDICO & $\begin{array}{c}\text { LUGAR DE } \\
\text { EDICIÓN }\end{array}$ & $\begin{array}{c}\text { FECHA DE } \\
\text { CREACIÓN }\end{array}$ \\
\hline La Gaceta de México y Noticias de la Nueva España & México & 1722 \\
\hline Mercurio de México & México & 1740 \\
\hline Diario Literario & México & 1768 \\
\hline Asuntos Varios sobre Ciencias y Artes & México & 1772 \\
\hline Mercurio Volante & México & 1772 \\
\hline Gaceta de Literatura de México & México & 1788 \\
\hline Gaceta de Lima & Lima & 1743 \\
\hline Diario de Lima, curioso, erudito, económico y comercial & Lima & 1790 \\
\hline Semanario Crítico & Lima & 1791 \\
\hline Mercurio Peruano & Lima & 1791 \\
\hline Gaceta de Guatemala & Guatemala & 1729 \\
\hline Gaceta de Santafé & Bogotá & 1785 \\
\hline Papel Periódico de Santafé de Bogotá & Bogotá & 1791 \\
\hline Correo Curioso, Erudito, Económico y Mercantil de la Ciudad de Santafé de Bogotá & Bogotá & 1801 \\
\hline Primicias de la Cultura de Quito & Quito & 1791 \\
\hline Gaceta de la Havana & La Habana & 1764 \\
\hline Papel Periódico de la Havana & La Habana & 1790 \\
\hline El Pensador & La Habana & 1790 \\
\hline Gaceta de Buenos Aires & Buenos Aires & 1764 \\
\hline Telégrafo Mercantil, Rural, Político-Económico e Historiógrafo del Río de la Plata & Buenos Aires & 1801 \\
\hline Gaceta Mensual de Costa Rica ${ }^{[1]}$ & & 1729 \\
\hline $\begin{array}{l}\text { [1] La Gaceta Mensual de Costa Rica aparece registrada en diversa bibliografía consultada; sin embargo, no ha sido } \\
\text { posible conseguir ningún ejemplar para confirmar esta información. Por su parte, la Biblioteca Nacional de Costa Rica, } \\
\text { según la comunicación mantenida con sus responsables, no conserva esta publicación periódica. }\end{array}$ \\
\hline
\end{tabular}

Hispánica con otras fuentes informativas procedentes del exterior que permitieran salvar la censura oficial ${ }^{11}$. Este mecanismo se evidenció nada más que comenzar el siglo, durante la Guerra de Sucesión española, como resultado del esfuerzo realizado por los países aliados para introducir gacetas en el Virreinato de Nueva España y en el Caribe; a modo de ejemplo, desde la isla de Curaçao se enviaban con asiduidad ejemplares de periódicos "subversivos" a la costa venezolana ayudando, de este modo, a generar un clima propicio para la proclamación del Archiduque Carlos de Austria en la ciudad de Caracas en $1702^{12}$; de igual modo, embarcaciones inglesas ${ }^{13} \mathrm{y}$

11 Una síntesis sobre el funcionamiento de la censura en la Monarquía Hispánica y en Europa puede verse en: SAVATER, Fernando: "Censura en la Europa Ilustrada", en BARREIRO BARREIRO, Xosé Luís, RODRÍGUEZ CAMARERO, Luis y GONZÁLEZ FERNÁNDEZ, Martín: Censura e Ilustración, Santiago de Compostela, Universidade de Santiago de Compostela, 1997, pp. 23-35.

12 La tarea propagandística impulsada desde la isla de Curaçao era conocida con detalle por el Consejo de Indias. AGI (Archivo General de Indias), Escribanía de Cámara, leg. 665B, pieza 12.

13 Entre otros muchos testimonios de esta actividad publicística, un barco inglés fue apresado por una fragata francesa y conducido al puerto de Santa Marta con diferentes "papeles subversivos" y una gaceta impresa que narraba los viajes efectuados por el Archiduque desde Viena a Portugal y posteriormente 
holandesas esparcían papeles periódicos con "novedades de guerras de Europa", cuya simple lectura era considerada por el aparato represor judicial una prueba concluyente para la acusación del delito de sedición ${ }^{14}$. Ciertamente, el control de los noticiarios procedentes de los países enemigos formó parte de la censura establecida durante los enfrentamientos $\operatorname{armados}^{15}$; aun así, las medidas de seguridad se extremaron, tanto en la Crisis Sucesoria española (1700-1714) con el fin de evitar la entrada de mensajes propagandísticos del bando adversario como durante la Guerra de la Convención (1793-1795) con objeto de impedir la llegada de las ideas revolucionarias francesas a los territorios de la Monarquía Hispánica; de ahí que en esta última coyuntura bélica fuesen prohibidos "los papeles públicos y gacetas de todos los reinos extranjeros 16 ". Precisamente, con ese mismo objetivo de evitar la circulación de planteamientos subversivos se promulgó la Real Resolución del 24 de febrero de 1791, promovida por Floridablanca, mediante la cual se prohibía en la Península Ibérica la publicación de papeles periódicos, a excepción del Diario de Madrid, el Mercurio histórico y politico y la Gaceta de Madrid ${ }^{17}$; no obstante, Carlos IV se mostró más permisivo con la actividad periodística en la América Hispana ${ }^{18}$, tal como lo demuestra la aparición pública en ese mismo año del Mercurio Peruano, Primicias de la Cultura de Quito, el Semanario Crítico y el Papel Periódico de Santafé de Bogotá.

\section{Las fuentes periodísticas}

Sin duda, las noticias sobre las operaciones militares, especialmente las relativas a los triunfos del propio ejército y a las derrotas de los enemigos, fueron temas recurrentes, tanto en la prensa europea como en la americana, hasta tal punto que se generó un flujo de informaciones bélicas que cruzaban el Atlántico de un lado a otro de manera que se publicaban en América textos extraídos de los periódicos peninsulares y en España se reproducían hechos divulgados previamente en los noticiarios impresos en los reinos de Indias; entre ellos, se advierte la reedición de levantamien-

al Principado de Cataluña. MENA GARCÍA, Ma . Carmen: Santa Marta durante la Guerra de Sucesión española, Sevilla, Escuela de Estudios Hispanoamericanos, 1982, p. 49.

14 Proceso judicial incoado por el Presidente de la Audiencia de Panamá contra Juan Antonio Luxillo por disponer de una gaceta clandestina y habérsela entregado a un ayudante para su lectura. AGI, Panamá, leg. 131.

15 En torno al funcionamiento de la censura periodística en el Setecientos puede verse: DOMERGUE, Lucien: "La prensa periódica y la censura en la segunda mitad del siglo XVIII", Estudios de historia social, 52-53 (1990), pp. 141-149.

16 Carta de Luis Antonio de Candamo firmada en Vitoria el 22 de septiembre de 1795. AHN (Archivo Histórico Nacional, Madrid), Estado, leg. 2906(2).

17 SÁNCHEZ HITA, Beatriz: "La prensa en Cádiz en el siglo XVIII", op. cit., p. 11.

18 Íbidem, p. 23. 
tos armados promovidos por los indígenas como el que fue descrito en un ejemplar de la Gaceta de Lima del año 1750, que fue impreso nuevamente en la ciudad de Sevilla con el fin de que fuese conocida esta sublevación por los españoles, así como el escarmiento ejemplarizante otorgado a los cabecillas de la revuelta por parte de las autoridades políticas y militares ${ }^{19}$. Precisamente el procedimiento de repetir los contenidos dirigidos a los lectores europeos en los medios de comunicación americanos llegó a provocar cierto cansancio en algunos de sus habitantes, quienes se manifestaron a fines del siglo XVIII a favor de que las noticias publicadas sobre las guerras se detuvieran en las consecuencias que originaban en sus lugares de residencia en vez de centrarse en la evolución de las operaciones bélicas en el viejo continente; de ello es ilustrativo una carta dirigida en 1797 al responsable de la Gaceta de Guatemala que sintetiza el sentimiento criollo frente a la «colonización periodística» de las temáticas europeas:

Señor editor: siete números lleva U. publicados de su periódico y hasta ahora no ha tocado ningún punto que sea de una utilidad directa de este Reyno. Será muy bueno todo lo que ha dicho U. de los altos y baxos de las potencias de Europa; pero a mí, que soy un Hacendado que vivo en este Reyno, y no pienso salir de él en los días de mi vida, poco me importa que suban o baxen los rusos, ni que se muevan o se estén quietos los prusianos. Quédense allá estas cosas para los cabilosos Estadistas; pero a mí, y a todos los demás de mi condición que no lo somos, diganos U. cosas que entendamos, y que nos toquen inmediatamente, y que puedan sernos útiles. Hay mil cuestiones luminosas que U. pudiera suscitar: por ejemplo: ¿Si la suerte del Hacendado es más o menos feliz en este Reyno que la del comerciante? ¿Si éste debe depender de aquél, o aquél de éste?. Y así algunas otras, que a U. que es tan gran político no dexarán de ofrecérsele. Todos los males que la guerra puede traer a las familias y a los Reynos, los sufrimos los Hacendados en ésta con los ingleses. Si U. hablase en su periódico de estos males y propusiese algún arbitrio hacedero para atajarlos por de pronto, y para precaberlos en lo succesibo; tendría U. colgados de sus discursos a todos los cosecheros, y especialmente a mí (...) Firmado. Manuel Agrícola ${ }^{20}$.

A pesar de este deseo expresado por algunos lectores, lo cierto es que la prensa española, principalmente la Gaceta de Madrid -medio de comunicación supervisado por la Administración Central21-, asumió la función de canal informativo entre la Península Ibérica y los reinos de Indias, de manera que los papeles periódicos ame-

19 Gazeta de Lima, que contiene las noticias desta capital desde 23 de julio hasta 14 de septiembre de 1750. HMM (Hemeroteca Municipal de Madrid), A-97.

20 Gaceta de Guatemala, $\mathrm{n}^{\circ}$ 10, 17 de abril de 1797. AGI, Gacetas 14/1, p. 80 .

21 EGIDO LÓPEZ, Teófanes: Opinión pública y oposición al poder en la España del siglo XVIII (1713-1759), Valladolid, Universidad de Valladolid, 2002, p. 35. 
ricanos se nutrían del contenido publicado previamente en ella. De esta evidencia se hacía eco expresamente la Gaceta de México, cuando manifestaba en sus páginas que suspendía la publicación de otras noticias llegadas por vía marítima, porque consideraba más interesantes las reflejadas en ocho ejemplares del rotativo madrileño enviados por la "Superioridad" que -según el editor- podían instruir al público sobre el "estado y progresos de la presente guerra ${ }^{22}$ ". En cualquier caso, la lentitud con que el correo trasatlántico introducía en América los diversos números del rotativo de la capital castellana motivaba que, con cierta frecuencia, los redactores se viesen obligados a recurrir a informaciones publicadas en otros países en el caso que éstas llegaran a Ultramar de forma más rápida; así sucedía, en ocasiones, con noticias de las gacetas de Lisboa que recalaban en Buenos Aires a través de la vía de Río de Janei$\mathrm{ro}^{23}$. Asimismo, los periódicos europeos o los editados en la isla de Jamaica -colonia de Gran Bretaña- sirvieron, incluso, para conocer los acontecimientos sucedidos en otros territorios del nuevo continente ${ }^{24}$; en efecto, las autoridades políticas hispanoamericanas dispusieron de informaciones sobre los desplazamientos y operaciones de las tropas "rebeldes" norteamericanas y del ejército de la Corona Británica durante la lucha por la independencia mediante gacetas procedentes del otro lado del océano Atlántico ${ }^{25} \mathrm{o}$, en su caso, a través de journals editados en la capital de esta isla caribeña. En concreto, un ejemplar del Journal de Kingston, publicado el 25 de noviembre de 1776 con el calificativo de "extraordinario", llegó a manos del Gobernador de La Habana en una embarcación de asiento de negros, y reproducía una carta de un vecino de New York que describía un panorama muy favorable a las fuerzas realistas, aunque lógicamente sujeto a una actitud apasionada atendiendo a la fidelidad de este individuo y del citado periódico a la Monarquía Británica; de este modo, el intérprete público de esta ciudad cubana traducía a lengua castellana el relato que el ciudadano

22 Gaceta de México, no 57, 9 de septiembre de 1794, p. 476.

23 Vid. Noticias recibidas de Europa por el Correo de España, y por la vía de Janeyro. BuenosAyres a 8 de Enero de 1781, n 1, Buenos Aires, Real Imprenta de los Niños Expósitos, 1781, p.1.

24 El Virrey del Perú adoptó decisiones militares, según su propio testimonio, en base a la información proporcionada "por nuestras gacetas y distintos papeles públicos de los yngleses venidos a mis manos..." CHAUCA GARCÍA, Jorge: "La defensa de la América Meridional durante la Segunda Mitad del Siglo XVIII: entre la amenaza inglesa y el impacto revolucionario francés”, en GUIMERÁ RAVINA, Agustín y PERALTA RUIZ, Victor (Coord.): El equilibrio de los imperios: de Utrecht a Trafalgar. Actas de la VIII Reunión Cientifica de la Fundación Española de Historia Moderna, vol. II, Madrid, Fundación Española de Historia Moderna, 2005, p. 644.

25 A modo de ejemplo, una información llegada al Gobernador de La Habana desde San Agustín de la Florida, en una carta de 16 de julio de 1776, ofrecía datos del curso de la guerra extraídos de los papeles periódicos europeos; en concreto, la citada misiva decía: "Ahora ha llegado noticia (pero no con certeza) que la Armada estaba haciendo embarque en una isla cercana a Charleston Carolina del Sur. Según las Gazetas de la Europa el cuerpo de tropas que hay en la América son forasteras, digo Rusianos, Prusianos y Alemanes, algunos Escoceses, y Montañeses; los Americanos tienen más de trescientos mil hombres bien disciplinados, y comandados por el General Lee..." AGI, Santo Domingo, 1598A. 
neoyorquino efectuaba de aquellos hechos el 28 de noviembre de 1776 con una cierta euforia que no presagiaba el desenlace final de la consolidación del proceso independentista formalizado en el Tratado de Paris de 1783:

El exército de los Rebeldes hera entonces muy numeroso, y fuertemente apostado en el Puente del Rey, y en el Río del Norte cerca de dicho Puente, en los Fuertes de la Independencia nominados Washington, Constitución, y Lee, defendido con líneas y reductos con 159 piezas de cañón exceptuando morteros, pero fueron todos tomados en dos semanas de tiempo con 3 ó 4000 prisioneros: gran parte del Exército Real se halla avanzado una distancia conciderable en las Jerseys, y devo decir que estará en Filadelfia antes de veinte días. 10.000 hombres se hallan ya embarcados, y deben partir mañana, o pasado mañana con seis navíos de línea y otras fragatas a una expedición secreta, pero se supone ser contra Rodeland, y su Providencia. Los vanos arrogantes rebeldes han mostrado una miserable figura sobre las armas, pues volavan delante de la tropa de S.M. lo mismo que un cardume de peces huye de un ballenato. Yo pienso que esto está cuasi rematado con estos miserables abandonados y también la campaña... ${ }^{26}$

De todas formas, la información obtenida a través de los noticiarios editados en territorios de otras potencias europeas no gozaban de toda la credibilidad de los redactores hispanos, ante la práctica extendida de ofrecer datos no veraces o interesados sobre el devenir de los acontecimientos bélicos ${ }^{27}$; de ahí que los periodistas hispanoamericanos se manifestasen proclives, siempre que fuera posible, a contrastar las noticias que aportaban los diferentes periódicos extranjeros que llegaban a las Indias; de este modo, la Gazeta de la Havana, de 22 de noviembre de 1782, daba cuenta de divergencias informativas publicadas en las gacetas holandesas e inglesas respecto al potencial naval de la Escuadra del Texel:

Del 12 del pasado escriben de Hull que no se creía hubiese salido entonces la Escuadra del Texel. Aunque los papeles Olandeses contaban hasta 47 navíos de línea y 49 entre fragatas y buques menores dando este total de las fuerzas de la republica por muy exacto, algunas gazetas inglesas aseguran que a fines de junio no pasaban de 31 los navíos que tenían prontos las Provincias Unidas incluyendo algunos de 50 cañones, pero el número de varcos de menor porte asciende a 56 según las mismas gazetas ${ }^{28}$.

26 Carta reservada del Gobernador de La Habana a José de Gálvez, 15 de enero de 1777. AGI, Santo Domingo, leg. 1598A.

27 Algunos ilustrados como José Celestino Mutis mostraban cierta desconfianza en la veracidad de toda la información incluida en las gacetas. Vid. SILVA Renán: Los ilustrados de Nueva Granada, 1760-1808. Genealogía de una comunidad de interpretación, Medellín, Fondo Editorial Universidad EAFIT, 2002, p. 336.

28 Gazeta de la Havana, Viernes, 22 de noviembre de 1782. Biblioteca Nacional "José Marti" (BNC). 
A pesar de que las fuentes foráneas contribuyeron a configurar el escenario bélico divulgado en los medios de comunicación escritos, la versión oficial de los sucesos militares se transmitía a través de los navíos de avisos -más rápidos que el grueso de la flota de Indias-, los cuales hacían circular desde los puertos los mensajes elaborados por la Administración de la Monarquía Hispánica. Ciertamente, los responsables de los papeles periódicos solían esperar a que arribasen estas embarcaciones con sus correspondientes "cajones de pliegos" antes de pronunciarse o de confirmar las noticias que transitaban por los diferentes virreinatos, pues esta fuente de autoridad sujeta al control del poder político era la que inducía a los redactores -si consideramos sus propios testimonios- a calificar solamente como verdaderos aquellos hechos que coincidiesen con los relatos distribuidos en los mencionados navíos. Sirva como muestra que acontecimientos producidos en la Península Ibérica o en la América Hispana durante la Guerra de los Siete Años no fueron objeto de la credibilidad pública de la Gaceta de Lima hasta que no se ratificaron por los "avisos"; precisamente este procedimiento impidió que previamente se dieran detalles de la rendición de la plaza de la Colonia de Sacramento materializada en 1762 por Pedro Cevallos -Capitán General de Buenos Aires-, de la ocupación de La Habana por las tropas inglesas ${ }^{29}$ o de las operaciones efectuadas ese mismo año en la frontera de Portugal por el ejército que estaba a las órdenes del Marqués de Sarriá ${ }^{30}$.

Desde luego, la dosificación de la difusión de las novedades durante los conflictos bélicos contemplaba el impacto que solían tener en la opinión pública las

29 En efecto, el periódico peruano prefirió aguardar la llegada de un navío de aviso que avalase la narración del triunfo de las tropas españolas en la plaza de Sacramento y el resultado del ataque inglés a La Habana; así se desprende de lo publicado en la prensa limeña: "Desde las últimas noticias recibidas en los caxones de pliegos por la vía de Chile el día 29 de diciembre del año próximo pasado, no se ha adelantado cosa alguna de particular, con que poder saciar al Público el justo deseo de saber los progresos de las armas españolas, contra las Naciones Británica y Portuguesa en la última Campaña fenecida por el mes de Noviembre de 62: ni menos dar con certeza los imaginados acaecimientos de la Habana, que tanto han inquietado los ánimos, por lo importante de su materia: Assimismo se ignoran después de la rendición de la Plaza y Colonia de Sacramento (hecha por el Excelentíssimo Señor Don Pedro Zeballos, Teniente Coronel de los Reales Exércitos de su Magestad, y Capitán General de Buenos Ayres, y Río de la Plata) los verdaderos sucesos; y se cree, podremos tener en el primer Aviso, según el plan en que estaban los proyectos de España, buenas noticias por lo perteneciente a la Guerra: como también por la vía de Panamá, y Chile las de la Habana, y colonia”. Gaceta de Lima, no 4, 20-1-1763 hasta 30-3-1763.

30 Lo dicho anteriormente quedaba reflejado con nitidez en unos comentarios periodísticos que se reproducen a continuación: "Por noticias particulares, que se han recibido por un aviso (que salió de Cádiz a fines de junio de este año, y llegó al Río de la Plata, a últimos de Septiembre) se comunica, que el Exército de la Frontera de Portugal mandado por el Marqués de Sarria había tomado varias plazas, y entre ellas la de Almeida, Berganza y Chabes; y aunque se anuncian otras noticias de más felices progresos, en las operaciones de esta campaña, por falta de los caxones de pliegos, que se asegura vienen conducidos en dicho aviso, no se pueden dar al público con aquella seguridad que se desea, lo que podrá ejecutarse en la siguiente gazeta con otras particularidades". Gaceta de Lima, n², 3 de diciembre de 1762 . 
victorias o derrotas de las propias fuerzas armadas o de los ejércitos enemigos ${ }^{31}$; no en vano, se constituía en un elemento publicitario que necesitaba ser medido y acompasado en el tiempo con el fin de no generar desmoralización en la población en situaciones coyunturales delicadas o, en su caso, excesos de confianza en los soldados que pudieran desincentivar la vigilancia y la prevención ante los adversarios. No obstante, los beneficios originados por los triunfos en los ánimos de los hispanos superaban con creces a cualesquiera otros efectos de forma que algunos papeles periódicos editaron noticias comunicadas por barcos mercantes o particulares de bandera española que indicaban los progresos de las fuerzas armadas nacionales sin esperar a las habituales verificaciones por conducto oficial, lo cual resultaba lógico atendiendo a las necesidades de carácter publicitario y a las dificultades que debían superar las embarcaciones de la Armada y los navíos de aviso para cruzar con regularidad temporal el océano Atlántico en épocas de disputas navales entre las potencias europeas $^{32}$. Además, la divulgación de este tipo de acciones protagonizadas por las tripulaciones privadas perseguía estimular el patriotismo y que fueran consideradas conductas modélicas; de esta línea argumental es representativa la noticia publicada en el Papel Periódico de Santa Fé de Bogotá durante la Guerra de la Convención, en la que se daba crédito en 1793 al testimonio ofrecido sobre las operaciones militares acontecidas en el Rosellón por el capitán de una embarcación que llegó a Cartagena de Indias procedente del puerto de Málaga:

El 14 de Setiembre entró en el Puerto de Cartagena el Bergantín particular la Resolución, su Capitán Don Joseph del Castillo, procedente de Málaga, con frutos y efectos: trae la noticia de haberse rendido a nuestras Armas el 25 de junio el Castillo de Bellegarde con novecientos prisioneros, y la de haber encontrado en el Estrecho la Escuadra del Almirante Hood, compuesta de 20 navíos y muchas fragatas, que iba a incorporarse con la nuestra, que quedaba cruzando sobre las costas de Cataluña y Francia. Es muy digno de elogio que los capitanes de las embarcaciones mercantes y particulares se interesen de este modo en traer unas

31 GONZÁLEZ CRUZ, David, "Celebraciones de victorias militares de la Monarquía Hispánica en sus dominios de Europa y América (siglos XVII y XVIII)”, en NÚÑEZ ROLDÁN, F., Ocio y vida cotidiana en el Mundo Hispánico en la Edad Moderna, Universidad de Sevilla, 2007, pp. 231-244.

32 A este respecto, la correspondencia que circulaba por vía marítima entre España y América precisaba escolta por parte de buques de guerra con objeto de evitarse la captura de las cartas por parte de los enemigos. Vid. Papel Periódico de la Havana, $\mathrm{n}^{\circ}$ 23, 22 de marzo de 1798. No obstante, el hecho de que las informaciones viajaran en embarcaciones de la Armada no garantizaba que todas ellas llegaran a puerto; de esta realidad es una muestra el suceso narrado por un impreso editado en Buenos Aires en 1781: "El oficial que trajo estas noticias echó al mar antes de ser apresado todos los papeles que trahía, reservando solamente la carta que contenía la relación del succeso, la qual escondió en sí pero no pudo evitar que fuese descubierta, y tomada por el Capitán que lo apresó..." Noticias recibidas de Europa por el Correo de España, y por la vía de Janeyro, op. cit., p. 3. 
noticias tan dignas del servicio del Rey, y de la pública aceptación, lo que acredita mucho patriotismo y zelo por la causa nacional. La noticia es ciertamente plausible porque la toma de dicho Castillo es muy considerable y honrosa para nuestras Armas (...) Es muy de creer que siendo cierta esta noticia, como nos persuadimos a que lo es, lograremos ver dentro de breves días verificados los gloriosos fines de la ilustre empresa de nuestras Armas... ${ }^{33}$

De igual modo, la prensa americana se mostró dispuesta a transmitir novedades bélicas obtenidas a través de determinados barcos extranjeros si éstas resultaban favorables a los intereses propagandísticos de la Monarquía Hispánica; en este sentido, sus redactores no tenían reparos en adelantarse a los conductos vinculados a la Administración del Estado si las informaciones aportadas por bergantines franceses, balandras holandesas o fragatas británicas -según el periodo de guerra de que se tratase- se ajustaban a las expectativas y a la estrategia diseñada para influir en la opinión pública $^{34}$. A este respecto, las alianzas militares con otros países o las diferentes actividades comerciales practicadas por las potencias europeas originaban que el tráfico portuario facilitase la circulación de las noticias proporcionadas por los mercaderes, marinos o pasajeros de otras nacionalidades, las cuales encontraban cauces de difusión cuando tenían un cariz positivo por referirse a derrotas de los enemigos o al cese de los enfrentamientos armados; de esto último es representativo que la Gaceta de Guatemala publicada en abril de 1798 divulgara como veraz el tratado de paz firmado por Francia y Austria, así como el reparto territorial establecido ${ }^{35}$.

33 Papel Periódico de Santa Fé de Bogotá, no 112, 18 de octubre de 1793.

34 En este marco, la Gaceta de Lima aludía al avance de las tropas españolas en Portugal mencionando como fuente a las embarcaciones que arribaban a los puertos de la América Hispana: "Por la vía de Panamá se nos comunican varias noticias, assí manuscritas, como relacionadas de pasageros, y de la Nueva Yor, que se condujeron en un Vergantín Francés de 14 cañones, y 100 hombres, su Capitán Monsiur Palanquier, que salió del Puerto del Príncipe en la Isla de Santo Domingo el 16 de Diciembre del año próximo pasado, habiendo arribado en 26 del mismo a dicho Puerto, por tener rota la Botabara, y hacer alguna agua, para dirigir su viaje a Curazao con carga de azúcar, café, etc. Y asimismo en otra Valandra Olandeza, que salió de Curazao, y llegó al expresado puerto el 15 de enero de este presente año, con carga de pólvora, balas, fusiles, arina, xamones y otros víveres: las noticias que enuncian son las siguientes. Que el Reyno de Portugal estaba quasi subyugado a nuestras Armas..." Gaceta de Lima, n 5, 30-3-1763 hasta 20-5-1763.

35 Así lo expresaba el periódico centroamericano: "Ayer fondeó en este puerto la Fragata de Guerra Británica procedente de Cádiz, de donde salió el 14 de febrero con 1500 balones de papel de cuenta de la Real Hacienda. Noticia que permaneciendo todavía la escuadra inglesa delante de aquel puerto tuvo que hacerse a la vela de noche. Se ratifica que concluyó su paz el Emperador, aunque no se expresan sus condiciones con certeza y puntualidad. Dícese, no obstante, que la República Francesa tendrá por límites el Rhin, inclusas las plazas de Maguncia y Coblenza. Quedan por el Emperador la Istria, la Dalmacia y otros estados de Venecia, inclusa la misma ciudad de este nombre". Gaceta de Guatemala, n ${ }^{\circ}$ 58, 21 de abril de 1798 . 
Sin duda, los medios de comunicación escritos se veían obligados a recurrir a vías de información paralelas a las gacetas, especialmente en tiempos de guerra en los que se acrecentaba la lentitud del correo que comunicaba a los dominios americanos con la Península Ibérica. De esta realidad quedaba registro expreso, entre otros, en un ejemplar de la Gaceta de Guatemala, en el que se indicaba que habían quedado retenidas en La Habana "cuatro correspondencias de España ${ }^{36 ", ~ l a s ~ r e l a-~}$ tivas al periodo comprendido entre noviembre de 1796 y febrero de 1797. En este contexto, las denominadas "papeletas" se convirtieron, en líneas generales, en el recurso más asiduamente empleado como sustituto de las gacetas europeas para surtir de contenidos a los órganos periodísticos americanos ${ }^{37}$. No obstante, en numerosas ocasiones los editores prefirieron esperar a que llegase la prensa oficial procedente de la metrópoli antes de divulgar los mensajes distribuidos mediante este procedimiento $^{38}$. Sin embargo, cuando los autores directos de las papeletas ocupaban cargos en la Administración del Estado o disponían de una credibilidad acreditada se optaba por hacer públicos los sucesos narrados atendiendo a la consideración política o social de éstos ${ }^{39}$; no en vano, se avalaban los datos recogidos en ellas aludiéndose a que habían sido proporcionados por personas "de alto carácter y dignidad 40 " o por "sujetos de conocimientos políticos y fino criterio ${ }^{41}$ ". Salvo las excepciones mencionadas, los

36 Gaceta de Guatemala, nº 23, 10 de julio de 1797.

37 Manuel de Enderica, juzgado por el Tribunal del Santo Oficio de la Inquisición de México, mencionaba a las gacetas y a las papeletas que eran enviadas desde España a América como fuentes de información cuyos contenidos no podían ser cuestionados por los súbditos; así lo afirmaba en 1794, durante la Guerra contra la Convención: "Con las operaciones de la guerra se dieron al público muchas materias para hablar en las papeletas y cartas que venían de España, y también en las gacetas; y al que no creía cerradamente todo lo que se decía contra la Francia, o dudava de la toma de Bayona, de Perpinán, de Londres, etc. Lo tenían por mal español; y así lo que me he propuesto es decir lo que he hablado y lo que he pensado, en el modo que ocurra, y de sierto que este Santo Oficio pueda juzgarme por mis palabras y por mis juicios". Archivo General de la Nación de México (AGNM), leg. 1335, exp. 15, fol. 5.

38 Esta conducta todavía se observaba en los primeros años del siglo XIX, como lo demuestra el papel periódico publicado en Buenos Aires: "Las gazetas llegarán de Montevideo al primer viento; y como las diferentes papeletas que corren, se hallan tan implicadas, omite el Editor su publicación hasta recibir aquéllas". Telégrafo Mercantil, rural, politico-económico e historiógrafo del Río de la Plata, $\mathrm{n}^{\circ}$ 14, 16 de mayo de 1801.

39 El papel periódico de la capital del Virreinato de Perú ofrecía noticias de los acontecimientos de la Guerra de los Siete Años gracias a las informaciones enviadas por la máxima autoridad de Panamá: "Por cartas, y papeletas, que ha remitido el Gobernador de Panamá; y assimismo de otros particulares con fecha de 19 de agosto, se dice que habiendo llegado el día 9 a Portobelo 30 prisioneros en distintas embarcaciones, entre los quales vino también el Capitán Ramón Fragela, Piloto mayor de la Real Armada (que salió de la Habana el día 17 de junio despachado por el Gobernador, con pliegos del Señor Presidente de Santo Domingo, y fue apresado por una fragata inglesa en el tránsito de la una a la otra Isla) refiere que los Ingleses se desembarcaron en dos divisiones en aquella Isla..." Gaceta de Lima, 3 de diciembre de 1762.

40 Gaceta de Lima, $\mathrm{n}^{\circ} 1,8$ de enero de 1794.

41 Gaceta de Lima, n 7, 12 de marzo de 1794. 
periodistas recelaban de la fiabilidad y certeza de esta fuente informativa, aunque al mismo tiempo manifestaban que la tardanza en recibir novedades de la situación que vivía Europa a causa de los conflictos bélicos les forzaba a extractar las papeletas repartidas en América con el fin de complacer a los "espíritus curiosos" que deseaban noticias a "cualquier precio", aunque careciesen de las garantías de autenticidad requeridas. A pesar de que los papeles periódicos con frecuencia fueron portavoces de ellas, los editores eran conscientes de las limitaciones que presentaban y por esta razón trataron de contrastar las referencias que aportaban expresando, a veces, la divergencia y disparidad de sus datos. Así sucedía, a modo de ejemplo, con el ejemplar de la Gaceta de Guatemala publicado el 19 de junio de 1797:

\begin{abstract}
Aunque nos hallamos sin correspondencia de España, y por consiguiente sin noticias positivas del estado de la Europa, se han esparcido algunas papeletas venidas de Cádiz con fecha de 3 de febrero por un barco mercante llegado a Vera-Cruz, y por otros conductos (...) Según papeletas recibidas de México el capitán de un barco bostonés que salió de Lisboa el 1 de Marzo ha confirmado el combate de nuestra esquadra, mandada por el Sr. Mazarredo, con la inglesa del Almirante Jervis, de que se dio noticia en la Gazeta número 16; pero atribuyendo el triunfo o las ventajas a la esquadra inglesa. Esto no merece mucho crédito si se atiende a que quien lo refiere es un bostonés procedente de Lisboa, donde oyó el suceso de boca de los mismos enemigos. Lo que parece cierto es que el combate se dio diez leguas al Oeste del Cabo de San Vicente, y que al otro día de este succeso apresó nuestra escuadra ocho o diez velas inglesas mercantes procedentes del Mediterráneo. Dícese también que hemos apresado un barco que conducía un grueso empréstito hecho por los portugueses a la Inglaterra. Hay una variedad notable en la suma de este empréstito. Dicen unas papeletas que ascendía a 4 millones de pesos; otras dicen que a 4 millones de portuguesas, que son 32 millones de aquella moneda...42
\end{abstract}

Unos meses más tarde, en octubre de ese mismo año, el periódico guatemalteco se pronunciaba de nuevo sobre el valor informativo de las papeletas llegando a afirmar de manera radical que eran siempre falsas en la "sustancia" y en el modo o accidentes que las hacían variar, ya fuese en parte o en su totalidad; además, descalificaban su veracidad argumentando que estaban sujetas a interpretaciones, caprichos y fines particulares $^{43}$. A pesar de estas críticas, los noticiarios americanos no pudieron escapar a

42 Gaceta de Guatemala, n 20, 19 de junio de 1797, pp. 158-159.

43 En estos términos quedaba expresado: "Quisiéramos que nuestros lectores nos exonerasen del trabajo de dar mensualmente este artículo, o por lo menos llevasen en paciencia que no le diésemos sino quando se reciben correos directos de España. Las noticias sueltas que da un barco recién llegado, y se comunican de unos pueblos a otros por cartas o papeletas son siempre falsas en la substancia, en el modo o en accidentes que la hacen variar ya en el todo o ya en una gran parte de él. En hechos de armas y ne- 
reproducir en sus páginas -por imperativo de la propia demanda de sus destinatarioseste tipo de fuente que llegaba a manos de sus redactores y que recorrían las principales ciudades de las Indias, desde Buenos Aires a Valparaíso, desde Veracruz a México, desde Cádiz a La Habana, entre otros muchos lugares de la geografía hispana.

Por su parte, los retrasos en la llegada de los navíos de aviso desde España -más frecuentes en las coyunturas bélicas- impulsaba también a que la prensa intentara suplir la carencia de noticias transmitidas por la Administración Central recurriendo a la difusión del contenido de la correspondencia que circulaba entre los distintos territorios americanos ${ }^{44}$, ya fuese aportada por autoridades políticas o por particulares; en este último caso, como era de esperar, se reseñaban las novedades aunque advirtiendo a los lectores que requerían de la consiguiente confirmación ${ }^{45}$. De este modo, solamente se consideraban como noticias veraces aquellas remitidas por los denominados "sujetos autorizados" integrados en la maquinaria de comunicación social de la Monarquía Hispánica ${ }^{46}$; por el contrario, los acontecimientos referidos en cartas de personas privadas, ajenas a los controles de los responsables gubernativos, no se acostumbraban a divulgar y, menos aún, si los editores estimaban que el cono-

gociaciones políticas no hay nadie que no se crea bastante sabio para dar su voto y formarse un sistema. De aquí resulta que las noticias oídas se interpreten, acomoden y tomen distinto aspecto de unos en otros. El capricho y los fines particulares entran también a la parte en esta interpretación de que se sigue que las especies muden de forma, que hagan alto unos en los otros no tocan sino muy de paso, y que se conviertan los enanos en gigantes, y los gigantes en enanos (...) A pesar de eso ¿el conducto es fidedigno? ¿Todas las noticias son ciertas? ¿Son verosímiles? Cada lector tiene amplia libertad de juzgar lo que le acomode en tanto que otras más exactas le sacan de su ilusión o ayudan a mantenerla en ella". Gaceta de Guatemala, $\mathrm{n}^{\mathrm{o}} 38,23$ de octubre de 1797.

44 A las noticias de guerra que llegaban desde la Península Ibérica en forma de cartas se refería el naturalista Mutis: "Jueves, 28 de enero (1762) Recibimos cartas de España con la llegada del Firme (navío de guerra de 74 cañones) a Cartagena. Supimos el infeliz estado de los negocios de Europa, y casi se nos anunciaba prontamente la guerra, pues todas las apariciones eran para presumirlo así. Un nuevo de esfuerzo de 1.000 hombres de tropa de tierra sobre la tropa que había desembarcado el mes de Julio transportada en los dos navíos de guerra..." MUTIS, José Celestino: Viaje a Santa Fe, Madrid, Historia 16, 1991, p. 191.

45 Este procedimiento fue adoptado por el periódico peruano: "Las noticias que hemos tenido son las siguientes: En cartas de la Habana de 3 de Marzo de este presente año asseguran haber entrado en Cuba 3 navíos de guerra, 2 fragatas, y 2 saetías, que salieron de España con dos batallones de infantería para la Isla de Santo Domingo, y 200 dragones para la plaza de la Habana, en donde se decía, que los ingleses habían puesto sitio a la Martinica (...) Por el Correo de Valles escriben de la ciudad de Quito, haber entrado en Cartagena registro de España. Esta noticia necesita confirmación”. Gaceta de Lima, nº 1, 10 de octubre de 1762 .

46 Este calificativo, como podemos comprobar, fue el otorgado a las personas que gozaban de la confianza política de los medios de comunicación oficiales: "En las cartas, que de sujetos autorizados de Guayaquil se ha recibido en el último Correo de Valles, se dá por noticia cierta, que los Ingleses habían levantado el Sitio de la Habana el día 10 de Agosto del año pasado, con pérdida considerable de su Tropa y Navíos. La primera precedida del valor con que se les había resistido, y del vómito negro que se les introduxo, como es regular en aquellos tiempos..." Gaceta de Lima, n 3, 3-12-1762 hasta 20-1-1763. 
cimiento de éstas podía originar consecuencias perjudiciales para los intereses de la Corona $^{47}$. No obstante, cuando se trataba de un suceso que podía influir de manera decisiva en el aumento de la moral del conjunto de la población y de las fuerzas armadas se valoraba en mayor medida el objetivo que se pretendía conseguir que la fiabilidad de la fuente; de ahí que el ansía de los hispanos por reintegrar a la Colonia de Sacramento a los dominios del Rey de España propiciara que la Gaceta de Lima anunciase, en base a unas cartas, la rendición de la citada plaza al Capitán General del Río de la Plata en enero de 1763:

Por las últimas cartas recibidas de Buenos Ayres, por la vía de Chile, se ha divulgado al público la noticia (de que estaba deseoso) de la rendición de la Plaza y Colonia del Sacramento, hecha por el Excelentíssimo Señor Don Pedro Zeballos, Teniente General de los Exércitos de S.M. Gobernador y Capitán General de Buenos Ayres y Río de la Plata: la que según dichas cartas sucedió el 28 de Octubre, después de algunos días de trinchera abierta. Esta noticia (que después de llenar de gloria a su Gefe, de tanta parte a los vecinos y comerciantes de la ciudad de Buenos Ayres, por haberse expuesto voluntariamente, y el comercio a su costa, según refieren dichas cartas, a conseguir para S.M. una Plaza, que era borrón de toda esta América meridional) ha dado tanta satisfacción y emulación a este Público, que solo sienten tener quien les haya precedido a manifestar lo ardiente de su zelo en servicio de Su Majestad... ${ }^{48}$

Ciertamente, cuando crecía la necesidad de que las páginas de los periódicos actuaran como resortes propagandísticos que colmaran los deseos y expectativas de los hispanoamericanos y les otorgaran seguridad en el triunfo final del ejército español, descendía la fiabilidad exigida a las fuentes informativas de manera directamente proporcional a los requerimientos de las coyunturas; hasta tal punto fue así que en ocasiones se aceptaron como verídicos los testimonios obtenidos, incluso, de personas de baja extracción social procedentes de territorios enemigos. Así sucedería con el anuncio realizado por la Gaceta de Guatemala en julio de 1797, pues daba crédito a los hechos narrados por dos desertores de color negro que habían residido en las colonias inglesas, cuyo aval le servía para justificar un supuesto avance de las armas españolas como consecuencia de dos ataques efectuados al lugar de Balis, que según estos dos testigos provocaron la escasez de víveres, la quema de las viviendas y numerosos daños a sus pobladores, así como la huída de la mayoría de las familias de raza blanca a la isla de Jamaica. Desde luego, el objetivo publicitario de esta noticia

47 Vid. Telégrafo Mercantil, rural, político-económico e historiógrafo del Río de la Plata, $\mathrm{n}^{\circ} 11$, 6 de mayo de 1801.

48 Gaceta de Lima, $\mathrm{n}^{\circ}$ 3, 3-12-1762 hasta 20-1-1763. 
era ratificado por el propio periódico guatemalteco cuando manifestaba que de estos datos se infería la facilidad con que las tropas hispanas podrían conseguir la victoria en el citado territorio; de ahí que expresase la predisposición a "creerlos mientras que no se sepa lo contrario" con el argumento de que no había motivo para sospechar que ambos tuvieran "mala fe $\mathrm{fe}^{49}$ ".

\section{Los papeles periódicos como instrumentos propagandísticos en tiempos de guerra}

Como se ha tenido la oportunidad de comprobar, resulta complicado desligar la información publicada en las gacetas americanas de los intereses publicitarios que impulsaban a los mensajes propagandísticos reproducidos en ellas; no hay que olvidar que estos medios de comunicación escritos estaban al servicio del poder político y controlados directamente por él con la finalidad de formar una opinión pública proclive a las decisiones de la Monarquía ${ }^{50}$. Este condicionante de partida explicaría la utilización de los periódicos para que fuesen portavoces de las tesis oficiales en materia de tratados de paz, de tratamiento e indultos otorgados a los prisioneros de los ejércitos enemigos, de contribuciones militares, de rituales religiosos de carácter bélico, entre otras cuestiones. En este contexto transmitían igualmente posicionamientos político-ideológicos, ya fuesen coherentes con la tradición del discurso neoescolástico español o, en su caso, netamente contradictorios con él; esta última situación se advierte con nitidez, a modo de muestra, en artículos e informaciones publicadas en dos periódicos hispanoamericanos, pues como consecuencia del cambio de alianzas respecto a Francia se ofrecía una imagen radicalmente diferente de este país y de sus gobernantes en el ejemplar del Papel Periódico de Santafe de Bogotá de 9 de mayo de 1794 frente al que se editó cuatro años más tarde en el Papel Periódico de la Havana de 6 de septiembre de 1798. Precisamente el número editado por el rotativo de Bogotá durante la Guerra contra la Convención realizaba una exposición estructurada en torno a los valores del Antiguo Régimen defendiendo una guerra denominada legítima y defensiva contra el deseo de los franceses de suprimir los gobiernos monárquicos de Europa; con este objetivo el artículo demonizaba a los revolucionarios

49 Gaceta de Guatemala, n 22, 3 de julio de 1797.

50 Matías de Gálvez, Virrey de Nueva España, expresaba su opinión en 1768 en relación con las temáticas específicas que debía abordar la prensa hispana: "Yo tengo la gaceta por muy útil, siempre que se reduzca a noticias indiferentes: entradas, salidas, cargas de navíos y producciones de la naturaleza; elecciones de prelados, de alcaldes ordinarios... Por otra parte, importa dar materia inocente en que se cebe la curiosidad del público". NÚÑEZ SÁNCHEZ, Jorge: "La crisis colonial y la insurgencia criolla", en Eugenio Espejo y el pensamiento precursor de la independencia, Quito, Ed. ADHILAC, 1992, p. 108. 
galos acusándolos expresamente de representar el desorden frente al orden y de tratar de fundamentar la libertad destruyendo las propiedades y creando un "sinnúmero de monstruos que devoran los bienes más preciosos de la Humanidad ${ }^{51}$ ". Sin embargo, el Tratado de San Ildefonso firmado por Godoy convertía en 1796 a España en una aliada de la Francia Revolucionaria y este hecho explicaría que una gaceta de perfil monárquico como la publicada en La Habana acogiese en sus páginas el discurso elaborado por el nuevo embajador francés elegido por el Directorio para la Corte de Madrid; no obstante, la difusión de un texto de esta naturaleza por los editores, que suponía una transformación de los mensajes expresados unos años antes en relación con los franceses, captaba cierta comprensión de los lectores gracias a la utilización de una estrategia propagandística que intentaba justificar el cambio producido en las relaciones diplomáticas del Gobierno español centrándose en los perjuicios que habían causado los enemigos ingleses a los hispanos a lo largo de los siglos. De ello era expresivo el mencionado discurso pronunciado por el ciudadano Truguet ante el rey Carlos IV, en el Real Sitio de Aranjuez el 11 de febrero de 1798, y publicado por el Papel Periódico de la Havana siete meses después:

Señor: el Directorio executivo de la República Francesa deseando mantener y cimentar más y más la alianza que une nuestras dos Naciones, me ha elegido por embaxador cerca de V.M. La garantía de esta alianza se apoya no solo sobre nuestros intereses comunes, sino sobre nuestros empeños sagrados y solemnes (...) Después de haber conquistado la paz del continente con una continuación de triunfos, nos queda que vencer un enemigo solo. Este enemigo es el de V.M. y el de toda la Europa, cuyo reposo no ha cesado de turbar: es el enemigo de la humanidad entera, cuyas santas leyes ultraja cada día: y los esfuerzos reunidos de las dos Naciones aliadas son los que deben castigar su fiero machiavelismo, y su sórdida ambición (...) No hablaré a V.M. de los traidores cuyas maquinaciones aun más pérfidas han servido ocultamente al partido Ingles. El Gobierno de la República los ha reconocido en su mismo seno, y los ha castigado y alejado; y V.M. sin duda hará justicia igualmente con todos los que se le señalen, pues son tan enemigos del Trono de V.M. como de la República. Amistad sincera, deferencia y lealtad con los Aliados; valor generoso contra los enemigos armados; desprecio y castigo para los traidores, son, Señor, los sentimientos del Pueblo Francés y de su Gobierno, y los que reclama, y espera de parte de sus aliados ${ }^{52}$.

En efecto, pese a las discrepancias ideológicas entre estados con regímenes políticos divergentes, la confluencia de intereses entre dos países por la existencia de un enemigo común era la explicación más coherente que tenía la posibilidad de ofrecer

51 Papel Periódico de Santafe de Bogotá, n 141, 9 de mayo de 1794.

52 Papel Periódico de la Havana, nº 70, 6 de septiembre de 1798. 
el poder vigente a través de la prensa americana. Desde luego, las circunstancias bélicas originadas por la evolución de las negociaciones diplomáticas transformaba las líneas editoriales de los noticiarios hasta el punto de que algunos de ellos colaboraron en la promoción del culto a la imagen de los líderes de la Revolución anunciando en la América Hispana la venta de retratos de Napoleón Bonaparte y de Robespierre en $1798^{53}$; sin embargo, cinco años antes, en plena persecución de las ideas procedentes de Francia, se vendían impresos en las mismas imprentas donde se editaban los periódicos en los que se acusaba a la Convención de ser opuesta a la "ley eterna" de Dios, a la religión cristiana, a la sociedad y a la Naturaleza ${ }^{54}$; es más, un ejemplar de Papel Periódico de la Havana publicitaba un cuaderno impreso al precio de cuatro reales titulado Poema heroico sobre la Asamblea, Constitución, o sea Convención nacional, en el que se arremetía contra los responsables de las instituciones galas en estos términos:

...pues no respiran más que sangre, horrores, tumultos, sediciones, seducciones, que con el fingido pretexto de alivio de los Pueblos son un perjuicio positivo, y con el especioso título de libertad una verdadera esclavitud del desgraciado Pueblo, y una indubitable tiranía de la Asamblea, como lo ha hecho manifiesto dentro de su propio Reyno, y en los Países que ha conquistado, dixe mal, usurpado: mas por medio del engaño, y de la seducción, que por la fuerza de las Armas. Compuesto por un Gaditano, zeloso de la honra de Dios, del amor y respecto debidos al Vicario de Jesucristo, a los Reyes y demás Superiores de la Tierra, así Eclesiásticos como Seculares ${ }^{55}$.

Desde luego, los acontecimientos bélicos de fines del siglo XVIII originaron negociaciones aparentemente contradictorias con la trayectoria anterior de la diplomacia española, por lo que el poder político precisaba por esta razón -más si cabe que en otros periodos de la centuria- la argumentación de las declaraciones de guerra y de los tratados de paz. De igual modo que podría ser considerada incongruente la alianza de Godoy y de Carlos IV con un estado republicano como el de Francia, también requería una adecuada justificación el convenio internacional firmado por los reyes de Gran Bretaña y de España en 1793; de ahí que aparecieran recogidos en la prensa hispanoamericana con la finalidad de que la explicación dada por la Corona obtuviera la mayor divulgación posible. En este sentido, la causa esgrimida en el mencionado

53 Papel Periódico de la Havana, nº 3, 11 de enero de 1798, y nº 68, 30 de agosto de 1798.

54 En este contexto, se anunciaba la venta de obras de cariz contrarrevolucionario como la que se reseña a continuación: "Se hallará en esta Imprenta hoy Domingo, al precio de un real, la respuesta de la Reina de Francia a la Convención Nacional, al significarla el decreto que ésta había expedido el 22 de marzo de 1793, por el qual la instaba que eligiese el Tribunal que la debía juzgar". Papel Periódico de la Havana, $\mathrm{n}^{\mathrm{o}} 76,22$ de septiembre de 1793.

55 Papel Periódico de la Havana, nº 62, 3 de agosto de 1794. 
tratado, y publicada por el Papel Periódico de Santafe de Bogotá en marzo de 1794, avalaba el cambio de posición del Gobierno respecto a Gran Bretaña -la nación que había sido la permanente enemiga de la Monarquía Hispánica- fundamentándolo en dos motivos: la seguridad de ambos países y la oposición a una guerra injusta y agresiva. Junto a la prensa oficial, los impresos editados por orden del Rey ${ }^{56}$ introducían un preámbulo en el que se intentaba conectar con la mentalidad social hispana anunciándose que el convenio nacía también como una respuesta a la conducta irreligiosa de los franceses con objeto de contrarrestar a los insurgentes, "castigarlos, y obligarlos a renunciar a sus detestables designios ${ }^{57 "}$. No cabe duda de que este mensaje vinculado a las convicciones espirituales de los hispanoamericanos contribuía a la aceptación, aunque fuese forzada por la coyuntura armada, de la colaboración que debían prestar a las embarcaciones inglesas proporcionándoles los "socorros" que necesitasen a los "precios corrientes"; sobre todo si se tiene en cuenta que los súbditos del otro lado del Atlántico tuvieron que soportar previamente durante décadas los ataques de piratas y de la fuerza naval británica a los puertos y zonas costeras.

Realmente, el periodo de la guerra contra la Francia revolucionaria generó en los rotativos americanos una evidente efervescencia propagandística manifestada en mensajes apasionados que calificaban a los partidarios del nuevo régimen francés de fanáticos, rebeldes, orgullosos, despechados, ilusos, falsos filósofos, irreligiosos, y autores de "atentados horrorosos e inauditos", entre otras consideraciones. Como es lógico, los ultrajes y abusos sufridos por la jerarquía eclesiástica en tierras galas y los sacrilegios cometidos en los templos abonaron el clima de "guerra de religión" que activó la consiguiente estrategia publicitaria que se encontraba al servicio de la Monarquía española con el objetivo movilizar a la población contra las nuevas ideas políticas ${ }^{58}$; este ambiente de represión en el país vecino propició que los periódicos hispanos se convirtiesen en plataformas de divulgación de los escritos redactados por prelados emigrados como fórmula de antídoto dirigida a evitar el contagio revolucionario en los súbditos ${ }^{59}$. De este modo, tras la muerte de Luis XVI y su familia, Carlos IV y sus colaboradores se mostraron partidarios de reafirmar públicamente la alianza con la je-

56 Real Cédula para que en los Reinos de Indias e Islas Filipinas, se observe el convenio provisional de alianza ofensiva y defensiva ajustado con Gran Bretaña. San Lorenzo, 6 de noviembre de 1793. Real Academia de la Historia (RAH, Colección Matalinares, tomo 116, Fol.. 500r-503r)

57 Papel Periódico de Santafe de Bogotá, nº 134, 21 de marzo de 1794.

58 Vid. GONZÁLEZ CRUZ, David: "La mentalidad religiosa católica en los conflictos bélicos de España y América durante el Antiguo Régimen: el siglo XVIII", en Religión y conflictos bélicos en Iberoamérica, Sevilla, Universidad Internacional de Andalucía, 2008, pp. 35-38.

59 En relación con la emigración del clero francés a España puede verse: MEIJIDE PARDO, María Luisa: Sacerdotes franceses emigrados durante la Revolución a Galicia, A Coruña, Edicios do Castro, 1991. 
rarquía eclesiástica insistiendo en el compromiso mutuo de protección de manera que la publicación de cartas pastorales de los obispos franceses respondía a la necesidad de "vacunar" a las conciencias individuales frente a los deseos de las autoridades galas de extender en todo el ámbito occidental los principios de igualdad y de soberanía nacional ${ }^{60}$. Fruto de esta convicción de la Administración Borbónica, el Mercurio Peruano y otros papeles periódicos reproducían textos confeccionados por algunos prelados franceses, de amplia extensión, que requerían incluso su división en varias entregas o capítulos; entre ellos pueden mencionarse la Versión de una carta pastoral del Señor Obispo de Tolon ${ }^{61}$, así como la Carta pastoral que con motivo de la sacrílega muerte dada a Luis XVI, rey de Francia, escribió Monseñor el Obispo de la Rochela al clero y fieles de su Diócesi, desde Guadalajara de España. Esta última misiva, inserta en el correspondiente lenguaje religioso, tuvo como funcionalidad esencial entre sus posibles lectores el ensalzamiento del régimen monárquico y de la continuidad dinástica, tal como puede observarse claramente en el siguiente fragmento:

Roguemos por toda la augusta Casa de los Borbones, a quien la muerte de Luis XVI da un nuevo resplandor, un nuevo lustre. Roguemos por el Rey y Reyna de España, Monarcas tan religiosos, y tan benéficos parientes, aliados, y amigos del Rey mártir que lloramos: a ellos les debemos la seguridad de que gozamos: ellos nos han procurado los consuelos y socorros de la hospitalidad. ¡Oxala que el Cielo vele siempre sobre sus personas! ¡Que ellos consoliden más, y más este Imperio, de quien son cabeza y ornamento! ¡Qué su nombre querido, y respetado de ambos Mundos, fixe largo tiempo el destino de este Pueblo antiguo, religioso y sabio que gobiernan! Y que sus descendientes, caminando sobre sus pisadas, hagan pasar de edad en edad una rica sucesión de virtudes y de gloria (...) Roguemos por todos los Reyes y Potencias de la Europa, a fin de que el Dios de los Exércitos sea su defensor, y su apoyo en esta guerra extraordinariamente injusta, que la rebelión y el regicidio tuvieron la osadia de declararles. Roguemos por todos los Pueblos, a fin de que el Dios de la Justicia y de la Paz los aparte de esta senda cruel, que conduce a todos los delitos, y que sería para ellos manantial de las más grandes desgracias, pues que visiblemente lleva a la destrucción de todo orden Moral, y Político ${ }^{62}$.

Por otro lado, los periódicos de la América Hispana fueron utilizados para publicitar la generosidad del Estado con los prisioneros capturados en las operaciones militares y con los desertores del propio ejército como medio para enaltecer a sus

60 RIVERO RODRÍGUEZ, Manuel: Diplomacia y relaciones exteriores en la Edad Moderna. De la cristiandad al sistema europeo, 1453-1794, Madrid, Alianza Editorial, 2000, p. 184.

61 Mercurio Peruano, $\mathrm{n}^{\mathrm{o}} 320,26$ de enero de 1794, $\mathrm{n}^{\circ} 321,30$ de enero de 1794, $\mathrm{n}^{\mathrm{o}} 322,2$ de febrero de 1794.

62 Mercurio Peruano, no 364, 29 de junio de 1794. 
máximos responsables. A este respecto, se trataba de ofrecer una imagen idealizada del trato a los soldados enemigos apresados, dentro de un espíritu de Antiguo Régimen en el que teóricamente se establecía el respeto al honor de los capturados con discursos de cariz humanitario e, incluso, de perfil religioso; sirva como muestra el artículo publicado en el Papel Periódico de Santafe de Bogotá en octubre de 1793, en el que se afirmaba que aunque los españoles hubieran estado precisados a tomar las armas contra los adversarios existía un "sagrado vínculo" entre la especie humana que obligaba a amar y compadecer a los semejantes, así como a seguir las recomendaciones del Evangelio que instaba a todos los cristianos a comportarse como hermanos. En línea con estos principios filantrópicos de connotaciones propagandísticas destinadas a la exaltación de la supuesta benevolencia de las autoridades hispanas, el mencionado noticiario reeditaba un extracto de la Gaceta de Madrid que reproducía las órdenes dadas a favor de la guarnición francesa vencida en la toma del castillo de Bellegarde -en la zona limítrofe entre el Rosellón y el Principado de Cataluña-, pues se afirmaba que con las medidas de salvaguarda adoptadas se pretendía evitarles insultos a sus componentes y protegerlos de cualquier posible arbitrariedad; así, al menos, se reseñaba de la siguiente manera en el bando dictado por el general Ricardos que penalizaba a los contraventores y que fue publicado para su cumplimiento por el ejército español y, con posterioridad, para el conocimiento de los lectores de la prensa peninsular y americana:

Debe respetarse la desgracia. Este principio que dicta la Humanidad, es propio de la generosidad Española: espera pues, el General que no habrá persona alguna que insulte con el gesto, el ademán, la palabra, o de otro modo a los prisioneros Franceses en su salida, tránsito y estancia, y que reflexionen que las contingencias de la Guerra pueden conducirlos a igual estado; pero si contra toda esperanza hubiese algún Soldado, Pisano, Arriero, u otro individuo que se propasase en lo más leve, insultando a los infelices, será inmediatamente preso, y sufrirá sin dilación seis carreras de baquetas. No puede persuadirse jamás el General que incurra en semejante falta de generosidad y educación ningún Oficial, ni otra clase de sujetos condecorados, pero en el remotísimo caso que sucediese, tomará el partido correspondiente y severo según el hecho y las personas. Quartel general de Boulou 25 de Junio de $1793^{63}$.

Asimismo, la divulgación de los indultos concedidos por la Corona a los desertores en los medios de comunicación escritos insinuaba la bondad de las decisiones de los reyes en cuanto que formalmente suponían el perdón a los que hubiesen cometido el delito de abandono de las fuerzas armadas; sin embargo, estas muestras

63 Papel Periódico de Santafe de Bogotá, n 113, 25 de octubre de 1793. 
públicas de pretendida generosidad que se repetían con frecuencia en tiempos de conflictos bélicos escondían tras de sí las deficiencias estructurales y económicas que padecían los ejércitos occidentales en el siglo XVIII -por supuesto, incluido el de la Monarquía Hispánica-; en efecto, como se ha tenido oportunidad de documentar ${ }^{64}$, la fórmula de la absolución de la pena a los soldados fugados ayudaba a solventar parte de estas carencias aumentando el número de los efectivos de las tropas cuando no se cubrían las vacantes de los regimientos por el procedimiento habitual de reclutamiento y, además, permitía obtener informaciones de carácter estratégico sobre los enemigos en relación con la cuantía de las armas de que disponían, sus planes de actuación, el número de militares y su posicionamiento sobre el terreno, el estado de ánimo de los combatientes y de la población civil, entre otras cuestiones. De esta forma, la generalización de un indulto solicitado a Carlos IV por dos desertores de los batallones de Marina tenía como finalidad, tal como él mismo reconocía en 1791, reintegrar al servicio activo a todos los militares huidos e incrementar de este modo el potencial del ejército; por ello, la mención a la "real clemencia" como causa de su resolución era mas bien resultado del lenguaje paternal que adoptaba la Corona para promover la fidelidad de los súbditos. De ello era prueba evidente el texto del real decreto editado en el periódico de la capital del Virreinato de Nueva Granada ${ }^{65}$ :

En consecuencia de esto, y de lo compadecido que estoy de la suerte de los desertores, he venido en declarar que los dos ya mencionados Juan Francisco Manuel España, y Andrés Maestre, han de gozar del indulto por la buena fé con que se presentaron: y al propio tiempo he tenido a bien ampliarlo a todos los desertores de las tropas de Marina y Exército que se hallan retraídos o prófugos por este delito, siempre que dentro del preciso término de dos meses, contados desde la publicación de este mi Real Decreto, los que estubieren en esta Península, e Islas adyacentes, y de quatro meses los que se hallaren fuera de mis Dominios, se presenten en sus respectivos Cuerpos a cumplir el tiempo que quando desertaron les restaba de su enganche o condena; para que aclarándoles las plazas, queden libres de la pena a que según Ordenanza se hicieron acreedores con su fuga. Y para que se verifiquen los efectos de mi Real clemencia, y aún sirva esta a contener semejantes delitos, comunicareis las órdenes correspondientes a la observancia de este indulto. Señalado de la Real mano de S.M. En Palacio 22 de Marzo de 1791.

Sin duda, la prensa de la América Hispana integró entre sus funciones, durante los conflictos armados del siglo XVIII, la implicación en la promoción del recluta-

64 Vid. GONZÁLEZ CRUZ, David: "La deserción en las fuerzas armadas españolas y extranjeras durante la Guerra de Sucesión: comportamientos y estrategias", en La Construcción de un estado militar. La Monarquía Española (1648-1814), Pamplona, Universidad de Navarra (En prensa).

65 Papel Periódico de Santafe de Bogotá, nº 19, 17 de junio de 1791. 
miento de recursos humanos destinados a la defensa y a las operaciones bélicas en general, al tiempo que impulsaron las aportaciones económicas de particulares, instituciones y colectivos sociales al Estado ${ }^{66}$. Si se tiene en cuenta que en los periodos de guerra los impuestos habituales obtenidos por la Hacienda pública no eran suficientes para costear los gastos del ejército no debe dejarse de ponderar la fructífera labor de acompañamiento realizada por los papeles periódicos en la captación de fondos; de esta manera, allí donde la Administración comenzaba a encontrar dificultades para incrementar la presión fiscal estos medios de comunicación escritos formaban a la opinión pública e incentivaban las conciencias en favor de las contribuciones denominadas "voluntarias" y dirigidas a la financiación de las fuerzas armadas. A este respecto, los editores diseñaban la estrategia de comunicación en esta materia manejando con sutileza los mensajes con el fin de influir en la mentalidad colectiva, pues como conocedores de las expectativas individuales en el escenario de lo público apelaban perspicazmente al honor de los donantes, a sus deseos de protagonismo social, a sus expectativas de ascenso y a los sentimientos religiosos como mecanismos para hallar una respuesta positiva y activa de los lectores y, por ende, de sus respectivos círculos de relaciones socio-culturales.

Precisamente, la necesidad del Virrey de Nueva España de disponer de cuerpos de milicias provinciales acantonados a causa de la declaración de guerra a Gran Bretaña fue el motivo inmediatamente utilizado por la Gaceta de México para publicitar en 1797 las ofertas que realizaron diferentes militares consistentes en servir en sus empleos renunciando al correspondiente sueldo ${ }^{67}$; como es lógico, esta noticia hábilmente insertada en sus páginas suponía una llamada de atención dirigida a la población novohispana que dejaba constancia de la existencia de unas responsabilidades

66 Este anuncio publicado en la prensa cubana respondía a esa doble funcionalidad de contribuir al incremento del alistamiento de efectivos militares y de recursos económicos para el Ejército: "Damos a beneficio de los señores subscriptores, en papel separado, un Discurso que excita a la reunión de un fondo para reclutar aquí o en España, Marinería o Tropa, que sirva en los Baxeles de S. M. conforme sus Augustas intenciones, manifestadas en Real Decreto de 27 de Agosto último". Papel Periódico de la Havana, $\mathrm{n}^{\circ}$ 99, 14 de diciembre de 1794.

67 Así se expresaban los ofrecimientos concretos: "El Señor Conde de la Contramina, Coronel del Regimiento de Milicias Provinciales de Infantería de Tlaxcala, servir este empleo sin el sueldo que le corresponde el tiempo que el Cuerpo de su mando exista en campaña. Don Lorenzo Angulo Guardamano, Teniente Coronel del mismo, idem. Don Manuel Antonio Fernández Flores y Don Vicente Ruiz de Bustamante, Capitanes del propio, idem. El Capitán de Milicias Don Ignacio Joseph García Illueca, residente en la Hacienda nombrada de la Y, 500 pesos por una vez, como voluntario donativo para ayuda de los gastos de la referida guerra. S.E. se ha servido aceptar estas ofertas, dando a los que tan generosamente las han hecho las debidas gracias en nombre de S.M. y en el suyo por esta apreciable demostración de lealtad, mandando se publiquen por la Gazeta, para no defraudarles del honor que les resulta de su reiterada prueba de amor a la Real Persona de S.M., y del interés que se toman por el bien del Estado y de la Nación”. Gaceta de México, nº 29, 18 de enero de 1797. 
que podían ser asumidas opcionalmente y que, por tanto, generaban menos resistencias y rechazo que si el poder político instaba de manera forzada al alistamiento de soldados y de oficiales.

Junto a este procedimiento que ayudó al crecimiento de los reclutamientos, los papeles periódicos centraron sus esfuerzos en promover los donativos destinados a la guerra insistiendo en discursos con contenidos que movilizaban a los hispanos tales como la defensa de la fe católica ${ }^{68}$ y la honra social que suponía la divulgación pública de una acción generosa en los anuncios oficiales insertados en la prensa. Sobre esta última premisa las autoridades virreinales se manifestaron favorables a que los nombres de los donantes fueran explicitados con objeto de no privarles -según ellos- de la "pública satisfacción" y, de este modo, fueran ejemplarizantes del honor que conllevaba a todos los contemporáneos las denominadas "pruebas de amor" ${ }^{69}$ al Soberano ${ }^{70}$. Con todo, pese al lenguaje que aludía a la fidelidad y al cariño al monarca como causas, la supuesta voluntariedad de las contribuciones se transformaba en una obligación casi ineludible como consecuencia de la presión que generaba en los súbditos la precisión de efectuar similares aportaciones económicas a las realizadas por personas pertenecientes al mismo colectivo socioprofesional ${ }^{71}$, pues así cada una de ellas preservaba el prestigio que gozaban entre los miembros de su comunidad; por otro lado, las propias cédulas reales y las órdenes de los virreyes editadas en los diferentes noticiarios condicionaban la libertad de los súbditos para actuar al advertirlos específicamente sobre las recompensas y distinciones notorias que tenían previsto otorgar a todos los que fueran benefactores de la Hacienda ${ }^{72}$. En este marco es obvio que, aparte de otras razones mencionadas, en ocasiones se establecía entre el pueblo y la Corona un sistema de intercambio de favores de forma que los registros de donaciones, ya fuesen publicados en las gacetas o ya fueran conservados en los archivos de la Administración, eran considerados como acreditativos de los méritos exigidos para la obtención de cargos y mercedes; esta práctica extendida a lo largo del siglo XVIII ya era observada

68 Mercurio Peruano, $\mathrm{n}^{\circ}$ 303, 28 de noviembre de 1793.

69 Gaceta de México, no 34, 15 de abril de 1797.

70 Así lo expresaba el periódico mexicano: "S.E. se ha servido aceptar estas ofertas, dando a los que tan generosamente las han hecho las debidas gracias en nombre de S.M. y en el suyo por esta apreciable demostración de lealtad, mandando se publiquen por la Gazeta, para no defraudarles del honor que les resulta de su reiterada prueba de amor a la Real Persona de S.M., y del interés que se toman por el bien del Estado y de la Nación”. Gaceta de México, n 29, 18 de enero de 1797.

71 Incluso había cuerpos profesionales que adoptaban acuerdos que comprometían a todos su integrantes; éste fue el caso, entre otros, del donativo de 300.000 pesos ofrecido por los comerciantes del Perú al Rey a principios de la década de los cuarenta del siglo XVIII con objeto de que fuera destinado a los gastos originados por la guerra contra los ingleses. AGI, Escribanía de Cámara, leg. 927, expediente sobre Bartolomé Pinto.

72 Gaceta de México, $\mathrm{n}^{\circ}$ 56, 20 de octubre de 1795. 
a principios de esta centuria, durante la Guerra de Sucesión, cuando todavía no habían surgido las gacetas en la América Hispana, al menos así lo reflejaba una real cédula dictada en Madrid el 8 de octubre de 1713, en la que se solicitaba a los reinos del Perú y de Nueva España un donativo para la pacificación de Cataluña ${ }^{73}$ :

... se exorte en mi Real nombre a todos mis fieles vasallos de éstos y los Reynos de las Yndias, Ministros de los Tribunales, y dependientes de ellos de cualquier calidad y condición que sean, tanto a eclesiásticos como a seglares, a que subministren un donativo general y proporcionado a los indispensables y necesarios gastos para sitiar por mar y tierra a Barcelona (...) Y ruego y encargo a los Arzobispos, y cavildos eclesiásticos concurran por su parte a contribuir con un Donativo gracioso para que su producto sirva al fin que va expresado, y que cada uno en la parte que le tocare exorte en su territorio y jurisdicción a mis vasallos para que lo ejecuten en la cantidad que su posibilidad les permitiere; y que por lo que toca a las ciudades, villas y lugares de ambos Reynos del Perú y Nueva España se observe la regla de nombrar una persona de la mayor confianza que acompañado de otra del Ayuntamiento hagan listas de los vecinos y habitantes de cada uno de ellos, con distinción de los que dieren donativo y de los que no lo dieren; y que se remitan por mi Consejo de Yndias a mis manos copias de las referidas listas con esta expresión: como assi mismo relación general distinta y clara de lo que cada uno en su territorio y jurisdicción juntaren y de las personas que lo hubieren contribuido, para tenerlo presente en lo que se les fuere ofreciendo...

Si atendemos a que la Corona se había prodigado durante los siglos precedentes en premiar con prebendas y oficios a los individuos seglares y eclesiásticos que habían prestado servicios al Estado ${ }^{74}$, es lógico que la coyuntura bélica de la última década del Setecientos se convirtiera en un periodo propicio -al amparo de las promesas sugeridas en los anuncios publicitarios- para efectuar aportaciones económicas a la Hacienda con la esperanza de que el esfuerzo personal revirtiera en forma de dádivas en los donantes o, en su caso, en los miembros de sus respectivas familias. De este tipo de conductas fueron significativas las dos ofertas realizadas en 1795 por Juan Bautista Fagoaga -vecino de México-, quien ponía 8.000 pesos a disposición de Carlos IV con la condición de que el Virrey de Nueva España recomendase a dos hijos suyos, como así hizo, para la concesión de la Cruz de Carlos III y el cargo de Alcalde del Crimen de la Audiencia ${ }^{75}$; posiblemente su pragmatismo y el premio

73 RAH, Colección Matalinares, tomo 101, fol. 451r-452v.

74 GONZÁLEZ CRUZ, David: Propaganda e información en tiempos de guerra. España y América (1700-1714), Madrid, Silex, 2009, pp. 215-219.

75 De esta propuesta es demostrativo el documento emitido en México por su el Virrey Branciforte con fecha de 27 de junio de 1796: “...que después de escrita su carta de 30 de noviembre de 95 de que es contextación la expresada Real orden se presentó Fagoaga pidiéndole recomendase a V.M. para la 
solicitado como compensación debieron satisfacer sus exigencias cuando pidió en razón a "su natural modestia se ocultase su nombre en la Gaceta ${ }^{76 "}$. A este procedimiento político-administrativo también se aferraba el teniente coronel Juan de Ojeda -Sargento Mayor de Campeche- al solicitar un ascenso a la tenencia de San Juan de Puerto Rico, pues acreditaba como mérito una contribución mensual de veinte pesos durante la guerra contra la Francia revolucionaria mediante una certificación expedida por el Contador y por el Tesorero de la Real Hacienda del Puerto de Campeche ${ }^{77}$.

Por último, los papeles periódicos fueron una plataforma pública de la Monarquía Hispánica destinada a hacer propaganda bélica a través de los ruegos y súplicas a Dios dirigidos -según los textos- a conseguir el "feliz éxito de las Armas Españolas". En efecto, con frecuencia, los diferentes medios de comunicación escritos reseñaban las diversas rogativas que se organizaban en las villas y ciudades americanas como fórmula para implicar a la sociedad civil en los conflictos militares y, al mismo tiempo, generarle la confianza necesaria en el triunfo final con objeto de que continuaran apoyando a la Corona; de este modo, desde el ámbito de las creencias y convicciones religiosas -aparte de las motivaciones espirituales que pudieran existir- se trataba de conformar una conciencia colectiva afín a los intereses políticos que sustentaban las contiendas armadas con el fin de disponer de una masa poblacional que no pusiera excesivas resistencias a los reclutamientos, donativos y demás contribuciones económicas, e incluso que colaborara con el ejército en la defensa de sus propios territorios. Ciertamente, el modo de publicitar las rogativas coordinó la capacidad de difusión de los púlpitos con el radio de acción de los papeles periódicos reforzándose la imagen de unidad que se pretendía transmitir y de participación de todos los colectivos de cada localidad, desde las elites hasta los sectores más popu-

pequeña cruz de Carlos $3^{\circ}$ a su hijo Dn Josef Mariano Diputado del Real Tribunal de Minería de aquella ciudad, y para honores de Alcalde del Crimen de aquella Real Audiencia a otro hijo suyo Dn. Josef María residente en esta Corte. Que tiene dada cuenta y recomendadas estas solicitudes por conducto de los respectivos Ministerios de Estado y Gracia y Justicia, creyendo las justas y muy propias para compensar los muy recomendables servicios del benemérito y anciano Padre Dn Juan Bautista, y alentar a sus hijos a que continúen con el celo, amor, fidelidad y desinterés con que se han distinguido sus ascendientes..." Archivo General de Simancas (AGS), Secretaría Guerra, leg. 6973, exp. 40, fol. 6v-7v.

76 AGS, Secretaría Guerra, leg. 6973, exp. 40, fol. 3v.

77 El mencionado certificado afirmaba lo siguiente: "Que el Teniente Coronel Don Juan de Ojeda, Sargento Mayor de esta Plaza, ha contribuido mensualmente veinte pesos desde el primero de Julio de mil setecientos noventa y tres hasta que publicada la paz con Francia en fin de diciembre de mil setecientos noventa y cinco cesó la referida donación, como todas las demás que gratuitamente hicieron los vasallos pudientes en esta Provincia para los gastos de la Guerra que tubimos con dicha Nación; no siendo menos recomendable este servicio efectivo que hizo al Real Erario, que el que le dictó su amor al de S.N. quando habiéndose tratado de armar un Corsario Buque, capaz de hacer a los enemigos dexar las costas de esta Provincia amenazadas de hostilidades, le nominó de Comandante el Señor Capitán General como oficial inteligente, y se ofreció generosamente a ir a la Campaña sin gratificación de mesa, criados, sobresueldo ni otro estipendio alguno..." AGS, Secretaría Guerra, leg. 7211, exp. 37, fol. 3. 
lares $^{78}$. Esta conjunción de la prensa ilustrada con la labor realizada por los clérigos hispanos se observa, entre otros muchos lugares, en los cultos preparados en el curato de Panotlan, dónde la responsabilidad asumida por su párroco fue mostrada como modelo por la Gaceta de México:

El día 19 del presente (abril de 1795) se celebró en este Curato misa solemne, presente unas bellísimas imágenes del Santísimo Patriarca, y de Santiago Apóstol, Patrón de España, para impetrar de Dios, nuestro Señor, por medio de la eficaz intercesión de los santos tan poderosos, los auxilios necesarios a favor de nuestras Armas, la conservación de las importantísimas vidas de nuestros Soberanos, y sobre todo la reducción de los rebeldes de enemigos. Con el mismo objeto el 20 se celebró otra misa solemne colocada en el Altar otra bellísima imagen de nuestra Madre y Señora de Guadalupe, en cuyo culto y obsequio fue esta función, y en ambos días se intentó exhortar al Pueblo por la voz de su Párroco, como antes también lo ha hecho, a que continúe con sus deprecaciones a mover al Todopoderoso en circunstancias tan urgentes ${ }^{79}$.

Ciertamente, los periódicos se constituyeron en portavoces de la diversidad de actividades que la jerarquía eclesiástica ponía al servicio de la maquinaria propagandística del Estado para inducir a los feligreses al compromiso con las empresas bélicas; de ahí que los templos americanos durante los periodos de enfrentamientos armados, al igual que los peninsulares, se convirtieron en escenarios de una amplia batería de celebraciones de misas, oraciones "pro tempore belli", novenarios, letanías, maitines, sermones, ejercicios espirituales, exposición del Santísimo Sacramento, confesiones y comuniones generales. Este conjunto de cultos, ya fuesen rogativas o ya fueran acciones de gracias al Todopoderoso, fueron completados con los repiques de campanas y las procesiones ${ }^{80}$, con el objetivo de extender su impacto audiovisual a

78 El interés por publicitar la asistencia masiva a las rogativas organizadas se aprecia en noticias como la que se reproduce a continuación: "Panotlan, 31 de Diciembre (1796). En el día 29 del presente, habiendo convocado a todos los principales de los Pueblos de esta Feligresía su Párroco el Dr. Don Urbano Antonio Díaz de las Cuevas, y precedido especial convite a personas distinguidas, celebró, patente el Divinísimo Sacramento, misa solemne para implorar los socorros necesarios en las presentes urgencias de Guerra contra los Ingleses, y alcanzar de la divina Magestad no sólo las más dulces bendiciones sobre las muy amadas personas de nuestros Católicos Soberanos y toda la Monarquía, sino también la deseada victoria contra los enemigos. En el día 31 de dicho mes, colocadas en el Altar mayor de dicha Parroquia, que se adornó y aseó ricamente, unas bellísimas imágenes de nuestra Madre y Señora de Guadalupe, del Santísimo Patriarca Señor San Joseph, y del Apóstol Santiago, Patrón de las Españas, se celebró de orden del referido Párroco otra misa solemne para el mismo fin, concluyendo ambas funciones con la Letanía de los Santos. En uno y otro día fue muy particular la música, siendo los Indios de la Doctrina los que cantaron y tocaron los instrumentos. El concurso fue muy numeroso, y todos explicaron sus vivos deseos con las más ardientes y fervorosas deprecaciones". Gaceta de México, nº 31, 8 de febrero de 1797.

79 Gaceta de México, no 30, 19 de mayo de 1795.

80 Como muestra, la prensa mexicana daba detalles de la procesión y rogativas realizadas a Nuestra Señora de los Remedios: "El 14 se condujo en Carroza desde su célebre Santuario hasta la Parro- 
los espacios públicos de cada localidad. A todo ello se sumaban las indulgencias concedidas por los prelados a quienes participaban en los actos; realmente, se trataban de unos recursos de incuestionable capacidad de movilización de las voluntades de los fieles si se tiene en cuenta que la mentalidad religiosa hispana tenía como uno de sus ejes principales la creencia en la salvación de las almas a través de los sufragios y las gracias absolutorias de los pecados otorgadas por los titulares de las diócesis ${ }^{81}$.

Resulta evidente, tras el análisis efectuado de los periódicos americanos publicados en tiempos de guerra, que estos medios de comunicación escritos se constituyeron en referentes del discurso oficial que debían seguir el conjunto de los súbditos de la Monarquía, así como de las correspondientes conductas que se les instaba a practicar, ya fuese como consecuencia de mensajes sutiles o como resultado de las órdenes dictadas por las autoridades políticas y recogidas en sus páginas. De este modo, se instrumentalizó la información intentando que las gacetas fueran soportes propagandísticos de las necesidades estratégicas del Estado siendo vehículos publicitarios de sus decisiones, al tiempo que filtros de dosificación de la publicación de las noticias; no en vano, la regulación de los "tiempos" en el conocimiento de los acontecimientos bélicos posibilitaba la amplificación o reducción del impacto que tenían las derrotas o las victorias militares en la conciencia colectiva de la sociedad. En este marco primaba el objetivo de influir en la opinión pública por encima de la fiabilidad de las fuentes informativas y de su veracidad; no en vano, los editores le concedían

chial de la Santa Vera-Cruz la Milagrosa Imagen de Nuestra Señora de los Remedios, y el siguiente 15 en solemne general processión, como es costumbre, a la Iglesia Metropolitana, en donde el inmediato (con el fin de pedirle asylo, el triumpho, y la victoria de la Armas Españolas en la constitución presente) se le comenzó, y continuó Novenario con las circunstancias que se observan en estas ocasiones". Mercurio de México, $\mathrm{n}^{\mathrm{o}} 150$, mayo de 1741.

81 Entre ellas pueden mencionarse, como se aprecia a continuación, las concedidas por los obispos de Oaxaca y Puebla: “... y para excitar a que los Fieles pidan al Todopoderoso por el triunfo de nuestras Armas y Exércitos, haciendo a este fin oración, ha concedido cuarenta días de indulgencias por sí y otros cuarenta por el Illmo. Señor Obispo de Puebla. Igualmente según sus facultades sólitas concedió por primera vez indulgencia plenaria a los que confesados y comulgados el día del Apóstol San Pedro hiciesen oración por las necesidades de España y de la Iglesia. Gaceta de México, nº 44, 6 de agosto de 1793. De igual modo, el prelado de la diócesis novohispana de Valladolid intentaba incentivar la participación en las rogativas de manera semejante: “... el día 25 del próximo pasado (febrero) comenzó otro tercero a la imagen de un Santo Crucifixo que se venera en su Iglesia, con misas cantadas, patente el Señor Sacramentado, Letanía Lauretana y preces que le corresponden. Y el Illmo. Señor Obispo de esta Diócesis, para alcanzar más la devoción, concedió cuarenta días de indulgencia a todas las personas que concurriesen, y plenaria a los que confesasen y comulgasen el último día, en el qual predicó el R.P. Lector de Prima Fr. Bernardo del Espíritu Santo un sermón fervoroso exhortando a la penitencia”. Gaceta de México, nº 15, 30 de marzo de 1795. 


\section{David}

González Cruz

crédito a las mismas fuentes periodísticas si convenía a la coyuntura bélica o, en su caso, extremaban la prudencia en la difusión si se preveía que pudieran originar algún efecto perjudicial. Con todo, la funcionalidad de los periódicos de la América Hispana no se circunscribía exclusivamente a crear en la población una imagen de los conflictos armados proclive a los intereses de la Corona, puesto que como se ha podido apreciar jugaron un papel destacado en la logística del Ejército incentivando el reclutamiento de soldados, contribuyendo a la obtención de recursos económicos necesarios para la financiación de las empresas bélicas y favoreciendo la participación de la sociedad civil en la defensa de los territorios, entre otras cuestiones. 